\title{
Pertumbuhan Tanaman Cengkih (Syzygium aromaticum (L.) Merr Perr) Belum Menghasilkan pada Berbagai Dosis Pupuk Organik dan Intensitas Naungan
}

\section{The Growth of Young Clove Plant (Syzygium aromaticum (L.) Merr Perr) on Several Dosage of Organic Fertilizer and Shading Intensity}

\author{
Ratih Sulistianingrum, Ade Wachjar*
}

Departemen Agronomi dan Hortikultura, Fakultas Pertanian, Institut Pertanian Bogor (Bogor Agricultural University), Jl. Meranti, Kampus IPB Darmaga, Bogor 16680, Indonesia Telp.\&Faks.62-251-8629353 e-mail agronipb@indo.net.id *Penulis untuk korespondensi: wachjarade@yahoo.co.id

Disetujui 7 Januari 2015/ Publish online 15 januari 2015

\begin{abstract}
The experiment was aimed to determine the optimum effect of combination of shading intensity and dosage of organic fertilizer on growth of young clove plant. The research was conducted at Bogor Agricultural University's Research Station, Cikabayan, Dramaga, Bogor, from September 2013 until February 2014. The experiment was arranged in Split Plot design with two factors and four replications. The main plot was shading intensity consisted of four shade degrees, that is $0 \%\left(I_{1}\right), 25 \%\left(I_{2}\right), 50 \%\left(I_{3}\right)$ and $75 \%$ $\left(I_{4}\right)$ shade, the sub plot was organic fertilizer consisted of five dosages, that is $0 \mathrm{~kg}\left(P_{1}\right), 2.5 \mathrm{~kg}\left(P_{2}\right), 5 \mathrm{~kg}$ $\left(P_{3}\right), 7.5 \mathrm{~kg}\left(P_{4}\right)$ and $10 \mathrm{~kg}\left(P_{5}\right)$ per plants. The result indicated that $10 \mathrm{~kg}$ dosage of fertilizer per plant showed 30.0\% higher increase on diameter of shoot at the fourth weeks after the treatment. Shading intensity didn't give any significant effect on growth of young clove. Plant with $2.5 \mathrm{~kg}$ dosage of fertilizer and $50 \%$ shading intensity showed $20.9 \%$ higher increase on height of plant at 16 weeks after the treatment. Plant with $5 \mathrm{~kg}$ dosage of fertilizer and 75\% shading intensity showed 26.9\% higher increase on diameter of stem at 12 weeks after the treatment.
\end{abstract}

Keywords: clove, organic fertilizer, shading, young plant

\section{ABSTRAK}

Penelitian ini bertujuan memperoleh dosis pupuk organik dan intensitas naungan yang optimum untuk pertumbuhan maksimum tanaman cengkih belum menghasilkan. Penelitian dilakukan di Kebun Percobaan IPB Cikabayan, Dramaga, Bogor, mulai bulan September 2013 sampai dengan Februari 2014. Rancangan percobaan yang digunakan adalah Rancangan Split Plot dengan dua faktor dan empat ulangan. Petak utama adalah perlakuan naungan dengan empat taraf intensitas yaitu $0 \%\left(I_{1}\right), 25 \%\left(I_{2}\right), 50 \%\left(I_{3}\right)$ dan $75 \%\left(I_{4}\right)$, sebagai anak petak adalah pupuk organik dengan lima taraf dosis yaitu $0 \mathrm{~kg}\left(P_{1}\right), 2.5 \mathrm{~kg}\left(P_{2}\right), 5 \mathrm{~kg}$ $\left(P_{3}\right), 7.5 \mathrm{~kg}\left(P_{4}\right)$ dan $10 \mathrm{~kg}\left(P_{5}\right)$ per tanaman. Hasil penelitian menunjukkan bahwa, dosis pupuk organik 10 $k g$ per tanaman dapat meningkatkan diameter tajuk tanaman cengkih 30.0\% dibandingkan dengan kontrol pada 4 minggu setelah perlakuan (MSP). Intensitas naungan secara tunggal tidak berpengaruh nyata terhadap pertumbuhan tanaman cengkih. Pemberian pupuk organik $2.5 \mathrm{~kg}$ per tanaman dengan intensitas naungan 50\% dapat meningkatkan tinggi tanaman cengkih sebanyak 20.9\% dibandingkan dengan kontrol pada $16 \mathrm{MSP}$, dan pemberian pupuk organik $5 \mathrm{~kg}$ per tanaman dengan intensitas naungan 75\% dapat meningkatkan diameter batang tanaman cengkih sebesar $26.9 \%$ dibandingkan dengan kontrol pada 12 MSP.

Kata kunci: cengkih, naungan, pupuk organik, tanaman belum menghasilkan 


\section{PENDAHULUAN}

Tanaman cengkih (Syzygium aromaticum (L.) Merr Perr) merupakan salah satu tanaman perkebunan yang penting dalam perekonomian Indonesia (Balittan, 1979). Komoditas cengkih banyak digunakan di bidang industri rokok kretek. Bermawie (1992) mengemukakan bahwa cengkih dapat pula dimanfaatkan dalam industri kosmetik, bahan baku pembuatan vanilin, farmasi serta pemanfaatannya pada teknologi pangan sebagai agen anti mikroba alami. Hasil kajian Balitan (2012) menunjukkan permintaan cengkih selama kurun waktu 2005 - 2010 terus meningkat sejalan dengan berkembangnya perindustrian yang berbahan baku cengkih. Kebutuhan cengkih untuk pabrik rokok kretek sejak tahun 2005 sebanyak 91 350 ton dan meningkat pada tahun 2010 menjadi 120000 ton. Sementara itu, produksi pada tahun 2010 hanya mencapai 98586 ton. Luas areal perkebunan cengkih pada tahun 2012 adalah 476 800 ha dengan produksi 71400 ton. Kebutuhan cengkih yang berkisar 100000 ton tiap tahunnya ini masih belum dapat memenuhi kebutuhan industri berbahan baku cengkih, sehingga harus dilakukan impor untuk menutupi kekurangannya. Negara potensial penghasil cengkih lainnya adalah Madagaskar, Tanzania, India dan Brazil (Balitan, 2012).

Langkah yang ditempuh untuk mengurangi jumlah impor cengkih adalah melalui perluasan areal tanam dan intensifikasi. Salah satu tindakan untuk mendukung perluasan areal tanam cengkih adalah penyediaan bahan tanam atau bibit (Balittan, 1979). Bibit yang digunakan untuk mencapai swasembada cengkih harus bermutu dan memiliki pertumbuhan yang baik. Penanaman di lapangan dilakukan saat bibit sudah berumur dua tahun. Pemeliharaan tanaman cengkih di lapangan setelah ditanam hingga berumur empat tahun harus intensif, karena pada umur $1-4$ tahun inilah masa kritis pertama dari tanaman cengkih (Hadiwijaya, 1983).

Pemupukan yang intensif, baik menggunakan pupuk organik maupun anorganik, merupakan salah satu kegiatan pemeliharaan tanaman muda di lapangan yang sangat penting. Pemanfaatan pupuk organik atau kompos merupakan salah satu upaya untuk meningkatkan kualitas dan produksi tanaman. Hal ini sekaligus untuk mengurangi penggunaan pupuk anorganik, karena selain harganya yang relatif lebih mahal, penggunaan pupuk anorganik yang berlebihan dapat menimbulkan dampak negatif terhadap lingkungan (Herman dan Goenadi, 1999).

Selain unsur hara, naungan juga berpengaruh terhadap pertumbuhan tanaman cengkih muda di lapangan. Tanaman cengkih yang baru ditanam hingga fase belum menghasilkan (TBM) umur tiga tahun membutuhkan naungan. Bila menggunakan bibit umur dua tahun, maka diperlukan naungan di lapangan selama satu tahun. Tanaman muda yang baru ditanam di lapangan perlu diberi peneduh dan pelindung untuk mencegah sinar matahari secara langsung dan terik yang dapat membakar daun (Hadiwijaya, 1983). Hal tersebut dapat mempengaruhi jumlah intensitas cahaya matahari yang mengenai tanaman. Oleh karena itu, pemberian naungan pada persentase tertentu dapat memberikan intensitas cahaya matahari yang sesuai untuk fotosintesis sehingga tanaman cengkih dapat tumbuh secara optimum.

\section{BAHAN DAN METODE}

Penelitian ini dilaksanakan di Kebun Percobaan IPB Cikabayan, Dramaga, Bogor. Percobaan dilakukan pada bulan September 2013 sampai Februari 2014. Bahan tanam yang digunakan adalah bibit tanaman cengkih tipe Zanzibar yang telah berumur tiga tahun. Selain itu, digunakan juga pupuk kandang yang berasal dari kotoran sapi, pupuk dasar yang terdiri atas pupuk Urea, SP-36 dan $\mathrm{KCl}$, serta bambu untuk tiang dan atap naungan.

Rancangan percobaan yang digunakan dalam percobaan ini adalah Rancangan Split Plot dengan dua faktor. Petak utama adalah perlakuan intensitas naungan sebanyak empat taraf, yaitu: intensitas naungan $0 \%\left(\mathrm{I}_{1}\right)$; intensitas naungan $25 \%\left(\mathrm{I}_{2}\right)$; intensitas naungan $50 \%\left(\mathrm{I}_{3}\right)$; intensitas naungan $75 \%\left(\mathrm{I}_{4}\right)$, sebagai anak petak adalah dosis pupuk organik yang terdiri atas lima taraf, yaitu tanpa pupuk organik $\left(\mathrm{P}_{1}\right)$, pupuk organik $2.5 \mathrm{~kg}$ $\left(\mathrm{P}_{2}\right)$, pupuk organik $5 \mathrm{~kg}\left(\mathrm{P}_{3}\right)$, pupuk organik 7.5 $\mathrm{kg}\left(\mathrm{P}_{4}\right)$, serta pupuk organik $10 \mathrm{~kg}\left(\mathrm{P}_{5}\right)$ per tanaman. Dengan demikian, terdapat 20 kombinasi perlakuan dan setiap kombinasi perlakuan diulang empat kali, sehingga terdapat 80 satuan percobaan. Analisis statistik yang digunakan adalah sidik ragam model rancangan Split Plot. Peubah-peubah yang dipengaruhi secara nyata pada uji $\mathrm{F}$ taraf $\alpha=5 \%$ diuji lebih lanjut dengan Duncan's Multiple Range Test (DMRT) untuk mengetahui antar perlakuan dosis pupuk organik dan intensitas naungan yang terbaik, sedangkan untuk mengetahui dosis pupuk organik dengan intensitas naungan optimum dilakukan uji kontras polinomial.

Masing-masing satuan percobaan digunakan satu tanaman, sehingga dibutuhkan 80 tanaman cengkih yang dipindahtanamkan ke lapangan dengan jarak tanam $8 \mathrm{~m} \times 8 \mathrm{~m}$ dan 
lubang tanam ukuran $60 \mathrm{~cm} \times 60 \mathrm{~cm} \times 60 \mathrm{~cm}$. Pupuk organik diberikan seluruhnya dua minggu sebelum tanam dengan dosis sesuai perlakuan, sedangkan pupuk dasar diberikan satu kali yaitu saat penanaman. Dosis pupuk dasar yang digunakan untuk masing-masing tanaman adalah Urea $0.25 \mathrm{~kg}$, SP-36 $0.15 \mathrm{~kg}$ dan $\mathrm{KCl} 0.12 \mathrm{~kg}$. Naungan dibuat dari bilah-bilah bambu dengan lebar $2 \mathrm{~cm}$ dan disusun sedemikian rupa dari utara-selatan sehingga menghasilkan presentase naungan yang sesuai dengan perlakuan. Intensitas cahaya dari perlakuan tanpa naungan adalah 11 $718 \mathrm{KJ} / \mathrm{m}^{2}$, dan untuk intensitas naungan $25 \%$, $50 \%$ dan $75 \%$ bertutur-turut adalah $8778 \mathrm{KJ} / \mathrm{m}^{2}$, $5880 \mathrm{KJ} / \mathrm{m}^{2}$ dan $2940 \mathrm{KJ} / \mathrm{m}^{2}$.

Pengamatan mulai dilakukan pada saat sebelum perlakuan terhadap peubah-peubah meliputi: tinggi tanaman, diameter batang, jumlah cabang, jumlah daun dan diameter tajuk. Pengamatan selanjutnya dilakukan pada saat 2 MSP (minggu setelah perlakuan) dengan selang waktu pengamatan setiap empat minggu selama lima bulan.

\section{HASIL DAN PEMBAHASAN}

\section{Kondisi Umum}

Dosis pupuk organik dan intensitas naungan secara tunggal tidak berpengaruh nyata terhadap pertumbuhan tanaman cengkih. Interaksi antara dosis pupuk organik dengan intensitas naungan nyata berpengaruh terhadap tinggi tanaman cengkih pada 4 dan 12 MSP serta diameter batang tanaman cengkih pada 4,8 dan 12 MSP (Tabel 1).

Tabel 1. Rekapitulasi hasil sidik ragam terhadap berbagai peubah yang diamati

\begin{tabular}{|c|c|c|c|c|c|c|}
\hline \multirow{3}{*}{$\begin{array}{l}\text { Peubah yang } \\
\text { Diamati }\end{array}$} & \multicolumn{6}{|c|}{ Sumber Keragaman } \\
\hline & \multirow{2}{*}{ Ulangan } & \multirow{2}{*}{$\begin{array}{c}\text { Intensitas } \\
\text { Naungan (I) }\end{array}$} & \multirow{2}{*}{$\begin{array}{c}\text { Dosis Pupuk } \\
\text { Organik (P) }\end{array}$} & \multirow{2}{*}{ Interaksi (IxP) } & \multicolumn{2}{|c|}{ KK $(\%)$} \\
\hline & & & & & $\mathrm{I}$ & $\mathrm{P}$ \\
\hline \multicolumn{7}{|c|}{ Tinggi tanaman } \\
\hline $4 \mathrm{MSP}$ & tn & tn & tn & * & 25.5 & 19.0 \\
\hline 8 MSP & tn & tn & tn & * & 24.6 & 18.9 \\
\hline 12 MSP & tn & tn & tn & * & 23.7 & 18.9 \\
\hline 16 MSP & tn & tn & tn & * & 22.7 & 18.2 \\
\hline \multicolumn{7}{|c|}{ Diameter batang } \\
\hline $4 \mathrm{MSP}$ & tn & tn & tn & * & 21.3 & 15.5 \\
\hline $8 \mathrm{MSP}$ & tn & tn & tn & * & 20.0 & 13.3 \\
\hline 12 MSP & tn & tn & tn & * & 21.5 & 13.0 \\
\hline 16 MSP & tn & tn & tn & tn & 21.2 & 15.3 \\
\hline \multicolumn{7}{|c|}{ Jumlah cabang } \\
\hline 4 MSP & tn & tn & tn & tn & 48.3 & 45.6 \\
\hline 8 MSP & tn & tn & tn & tn & 47.2 & 44.9 \\
\hline 12 MSP & tn & tn & tn & tn & 52.3 & 50.0 \\
\hline 16 MSP & tn & tn & tn & tn & 58.9 & 49.1 \\
\hline \multicolumn{7}{|c|}{ Jumlah daun } \\
\hline 4 MSP & tn & tn & tn & tn & 33.7 & 45.7 \\
\hline $8 \mathrm{MSP}$ & tn & tn & tn & tn & 49.4 & 47.6 \\
\hline 12 MSP & tn & tn & tn & tn & 50.9 & 50.9 \\
\hline 16 MSP & tn & tn & tn & tn & 54.3 & 52.7 \\
\hline \multicolumn{7}{|c|}{ Diameter tajuk } \\
\hline $4 \mathrm{MSP}$ & tn & tn & * & tn & 27.4 & 28.1 \\
\hline $8 \mathrm{MSP}$ & tn & tn & tn & tn & 26.3 & 27.2 \\
\hline 12 MSP & tn & tn & tn & tn & 25.7 & 26.9 \\
\hline 16 MSP & tn & tn & tn & tn & 23.7 & 26.4 \\
\hline
\end{tabular}

Keterangan: I : intensitas naungan; P : dosis pupuk organik; KK : koefisien keragaman; ${ }^{*}$ : berpengaruh nyata pada uji $\mathrm{F}$ taraf $\alpha=$ $5 \%$; th : tidak berpengaruh nyata pada uji $\mathrm{F}$ taraf $\alpha=5 \%$; MSP : minggu setelah perlakuan.

Terdapat beberapa bibit yang mati setelah minggu pertama dan kedua pemindahan tanaman ke lapangan, sehingga harus disulam. Salah satu penyebab kematian bibit adalah serangan rayap (Coptotermes sp.) yang menyebabkan $8.75 \%$ tanaman yang dipindah tanam mati di lapangan. Tanaman yang terserang rayap menunjukkan gejala layu, daun mengering tapi tidak rontok dan bila digali sampai $10 \mathrm{~cm}$ di bawah permukaan tanah, tampak perakaran rusak bekas serangan rayap. Pengendalian dilakukan dengan pemberian Furadan 3G kurang lebih 5 g per tanaman dan penyiraman dengan termitisida konsentrasi $2 \mathrm{ml} / \mathrm{L}$ diaplikasikan setiap bulan selama tiga bulan pertama. Serangan hama lainnya yaitu kutu-kutu daun yang menghisap makanan dari pucuk-pucuk daun muda. Kutu-kutu tersebut mengeluarkan zat gula yang disenangi semut, dan sisa-sisa zat gula 
tersebut menempel pada daun yang dapat menimbulkan jelaga pada daun, tetapi hama tersebut tidak sampai menyebabkan kematian pada tanaman cengkih. Penyebab lainnya dari kematian tanaman cengkih yaitu sunburn yang dialami oleh tanaman tanpa naungan sebanyak $3.75 \%$ dari tanaman yang dipindah tanam ke lapangan. Intensitas cahaya yang terlalu tinggi menyebabkan peningkatan suhu daun sehingga laju transpirasi meningkat. Hal tersebut mengakibatkan luas daun mengecil atau daun gugur kemudian tanaman mati seperti yang dilaporkan oleh Suarsana (1986). Selain rayap dan sunburn, kesalahan teknik penanaman yaitu tanah dalam polybag pecah (tanah terlepas dari akar tunggang) ketika akan dipindahtanam dapat mengakibatkan bibit menjadi layu dan mati (Hadiwijaya, 1983). Sebanyak 5\% yang dipindahtanamkan ke lapangan mati karena kesalahan teknik penanaman tersebut.

\section{Pengaruh Naungan}

Pertumbuhan tanaman adalah interaksi antara faktor-faktor genetik dan lingkungan. Tanaman cengkih belum menghasilkan di bawah naungan dengan intensitas tertentu memiliki pertumbuhan tanaman lebih baik dibandingkan dengan tanaman tanpa naungan. Ada beberapa masa kritis dalam perkembangan tanaman cengkih. Salah satu dari masa kritis tersebut adalah fase yang dimulai sejak tanaman dipindahtanamkan ke lapangan hingga berumur kurang lebih empat tahun, yaitu dua tahun atau tiga tahun setelah pindah tanam ke lapangan (Hadiwijaya, 1983).

Pemberian naungan tidak menunjukkan peningkatan pertumbuhan tanaman yang signifikan seperti pada Tabel 2 untuk semua perlakuan hingga akhir percobaan. Hal tersebut diduga disebabkan oleh naungan yang dipasang terlalu tinggi dan kurang lebar, sehingga tidak berfungsi dengan baik. Hal ini sesuai dengan pernyataan Hadiwijaya (1983), bahwa naungan yang dipasang terlalu tinggi $(>30 \mathrm{~cm}$ di atas pucuk tanaman) tidak berfungsi dengan baik. Pada percobaan ini, tinggi tanaman berkisar $68-79 \mathrm{~cm}$ dengan ketinggian naungan mencapai $1.5 \mathrm{~m}$ menyebabkan selisih yang cukup jauh antara pucuk tanaman dan naungan sehingga mengakibatkan fungsi naungan kurang optimal. Selain itu, banyaknya pohon kelapa yang berada di sekitar lokasi penelitian juga menyebabkan fungsi naungan kurang optimal.

Perlakuan intensitas naungan yang tidak menunjukkan pengaruh signifikan terhadap tanaman cengkih pada penelitian ini mungkin disebabkan oleh tidak ternaunginya bagian sisisisi tanaman. Selaras dengan hasil penelitian yang dilakukan Wachjar et al. (2002), perlakuan naungan tidak berbeda pada semua peubah diduga karena tidak ternaunginya bagian sisi-sisi petak tanaman kopi. Rata-rata nilai peubah yang diamati pada berbagai intensitas naungan umur 4-16 MSP tercantum pada Tabel 2.

Tabel 2. Rata-rata nilai peubah yang diamati pada berbagai intensitas naungan umur 4-16 MSP

\begin{tabular}{ccccc}
\hline \multirow{2}{*}{ Peubah Pengamatan } & \multicolumn{4}{c}{ Intensitas Naungan $(\%)$} \\
\cline { 2 - 5 } & 0 & 25 & 50 & 75 \\
\hline Tinggi tanaman & $\ldots \ldots \ldots \ldots \ldots(\mathrm{cm}) \ldots \ldots \ldots \ldots \ldots \ldots$ \\
4 MSP & 72.6 & 73.1 & 75.5 & 68.3 \\
8 MSP & 74.5 & 74.9 & 76.7 & 70.2 \\
12 MSP & 75.9 & 76.5 & 78.0 & 72.3 \\
16 MSP & 78.0 & 78.0 & 79.3 & 74.2 \\
Diameter batang & $\ldots \ldots \ldots \ldots \ldots . .(\mathrm{cm}) \ldots \ldots \ldots \ldots \ldots \ldots$ & \\
4 MSP & 0.6 & 0.6 & 0.6 & 0.6 \\
8 MSP & 0.6 & 0.7 & 0.7 & 0.7 \\
12 MSP & 0.7 & 0.7 & 0.7 & 0.7 \\
16 MSP & 0.7 & 0.8 & 0.7 & 0.8 \\
Jumlah cabang & $\ldots \ldots \ldots \ldots \ldots . .(\mathrm{cm}) \ldots \ldots \ldots \ldots \ldots \ldots$ & \\
4 MSP & 12 & 14 & 12 & 13 \\
8 MSP & 14 & 16 & 14 & 15 \\
12 MSP & 16 & 19 & 16 & 18 \\
16 MSP & 17 & 20 & 18 & 19 \\
Jumlah daun & $\ldots \ldots \ldots \ldots \ldots . .(\mathrm{cm}) \ldots \ldots \ldots \ldots \ldots \ldots$ & \\
4 MSP & 118 & 129 & 133 & 127 \\
8 MSP & 109 & 121 & 126 & 121 \\
12 MSP & 142 & 140 & 148 & 145 \\
16 MSP & 191 & 205 & 195 & 199 \\
Diameter tajuk & $\ldots \ldots \ldots \ldots \ldots . .(\mathrm{cm}) \ldots \ldots \ldots \ldots \ldots \ldots \ldots \ldots \ldots$ \\
4 MSP & 25.6 & 23.4 & 24.8 & 25.1 \\
8 MSP & 27.0 & 25.1 & 26.3 & 26.9 \\
12 MSP & 27.4 & 25.9 & 27.2 & 27.4 \\
16 MSP & 28.4 & 26.4 & 28.2 & 28.1 \\
\hline
\end{tabular}

\section{Pengaruh Dosis Pupuk Organik}

Pemberian pupuk organik tidak berpengaruh nyata terhadap pertumbuhan tanaman cengkih hingga akhir percobaan. Salah satu kelemahan dari pupuk organik adalah unsur hara sangat lambat tersedia (slow release), sehingga respon tanaman terhadap pemberian pupuk organik berlangsung sangat lambat. Pangaribuan et al. (2012) menyatakan bahwa pemberian pupuk organik perlu dikombinasikan dengan pemberian pupuk anorganik yang menyediakan unsur hara dengan cepat. Selain itu, keefektifan pemberian pupuk organik kurang dari empat bulan, sehingga setelah empat bulan harus dilakukan pemberian ulang (Santosa, 2003).

Dosis pupuk organik cenderung berpengaruh nyata terhadap pertumbuhan diameter tajuk hanya pada umur 4 MSP. Pada 
dasarnya unsur hara yang tersedia dalam tanah dimanfaatkan oleh tanaman sesuai dengan kebutuhannya untuk pertumbuhan (Wachjar et al., 2002). Tidak adanya bulan kering selama penelitian mengakibatkan unsur hara di dalam tanah dapat diserap dengan baik oleh perakaran tanaman dan translokasi unsur hara ke daun serta proses pertumbuhan dan perkembangan tanaman menjadi baik (Wachjar dan Kadarisman, 2007). Selama percobaan ini berlangsung, curah hujan rata-rata adalah $411 \mathrm{~mm} /$ bulan (BMKG, 2014). Rata-rata nilai peubah yang diamati pada berbagai dosis pupuk organik umur 4-16 MSP tercantum dalam Tabel 3.

Tabel 3. Rata-rata nilai peubah yang diamati pada berbagai dosis pupuk organik 4-16 MSP

\begin{tabular}{|c|c|c|c|c|c|}
\hline \multirow{2}{*}{$\begin{array}{c}\text { Peubah } \\
\text { Pengamatan }\end{array}$} & \multicolumn{5}{|c|}{ Dosis Pupuk Organik (kg) } \\
\hline & 0 & 2.5 & 5.0 & 7.5 & 10 \\
\hline \multicolumn{6}{|l|}{ Tinggi tanaman } \\
\hline $4 \mathrm{MSP}$ & 68.6 & 74.9 & 70.9 & 73.9 & 73.3 \\
\hline $8 \mathrm{MSP}$ & 71.0 & 76.3 & 72.3 & 75.8 & 74.9 \\
\hline 12 MSP & 73.2 & 78.1 & 73.9 & 76.9 & 76.0 \\
\hline $16 \mathrm{MSP}$ & 75.5 & 79.6 & 76.1 & 78.3 & 77.2 \\
\hline \multicolumn{6}{|l|}{ Diameter batang } \\
\hline $4 \mathrm{MSP}$ & 0.6 & 0.7 & 0.6 & 0.6 & 0.6 \\
\hline $8 \mathrm{MSP}$ & 0.7 & 0.7 & 0.7 & 0.7 & 0.7 \\
\hline $12 \mathrm{MSP}$ & 0.7 & 0.7 & 0.7 & 0.7 & 0.7 \\
\hline $16 \mathrm{MSP}$ & 0.7 & 0.7 & 0.8 & 0.8 & 0.8 \\
\hline \multicolumn{6}{|l|}{ Jumlah cabang } \\
\hline $4 \mathrm{MSP}$ & 11 & 14 & 14 & 13 & 13 \\
\hline $8 \mathrm{MSP}$ & 13 & 16 & 15 & 15 & 14 \\
\hline 12 MSP & 15 & 19 & 18 & 18 & 16 \\
\hline $16 \mathrm{MSP}$ & 16 & 20 & 19 & 19 & 18 \\
\hline \multicolumn{6}{|l|}{ Jumlah daun } \\
\hline $4 \mathrm{MSP}$ & 110 & 130 & 137 & 133 & 123 \\
\hline $8 \mathrm{MSP}$ & 108 & 123 & 127 & 125 & 113 \\
\hline $12 \mathrm{MSP}$ & 125 & 158 & 152 & 150 & 132 \\
\hline $16 \mathrm{MSP}$ & 170 & 225 & 200 & 211 & 181 \\
\hline \multicolumn{6}{|l|}{ Diameter tajuk } \\
\hline $4 \mathrm{MSP}$ & $22.3^{\mathrm{b}}$ & $24.1^{\mathrm{ab}}$ & $23.9^{a b}$ & $24.2^{\mathrm{ab}}$ & $29.0^{\mathrm{a}}$ \\
\hline $8 \mathrm{MSP}$ & 24.0 & 26.0 & 25.2 & 26.1 & 30.3 \\
\hline $12 \mathrm{MSP}$ & 24.6 & 26.9 & 25.8 & 26.8 & 30.7 \\
\hline $16 \mathrm{MSP}$ & 25.7 & 27.5 & 26.8 & 27.6 & 31.4 \\
\hline $\begin{array}{r}\text { Angan } \\
\text { wakt } \\
\text { nyata } \\
\text { Ming }\end{array}$ & angka & yang & kuti & uf sa & $\begin{array}{l}\text { pada } \\
\text { erbeda } \\
\text { MSP : }\end{array}$ \\
\hline
\end{tabular}
Pengaruh Interaksi Pupuk Organik dengan
Intensitas Naungan

Pengaruh interaksi antara dosis pupuk organik dengan intensitas naungan terdapat pada peubah tinggi tanaman dan diameter batang tanaman cengkih. Tabel 4 menunjukkan Tanaman yang diberi pupuk organik $2.5 \mathrm{~kg}$ dengan intensitas naungan $50 \%$ nyata lebih tinggi dibandingkan dengan perlakuan lainnya.
Pertumbuhan dan perkembangan tanaman yang optimal akan dapat dicapai bila proses fotosintesis tanaman berjalan baik, dan hal ini sangat ditentukan oleh ketersediaan air, $\mathrm{CO}_{2}$, intensitas cahaya, suhu dan ketersediaan unsur hara. Intensitas cahaya yang meningkat akan menyebabkan peningkatan suhu, dengan optimalnya suhu maka akan memperlancar proses metabolisme dalam sel. Peningkatan pertumbuhan tanaman akibat pemupukan terjadi sampai pertumbuhan optimal, jika berlebih dapat menghambat dan mengganggu pertumbuhan tanaman (Maryani dan Gusmawartati, 2011).

Tabel 4. Pengaruh dosis pupuk organik dengan intensitas naungan terhadap tinggi tanaman cengkih belum menghasilkan pada umur 4-16 MSP

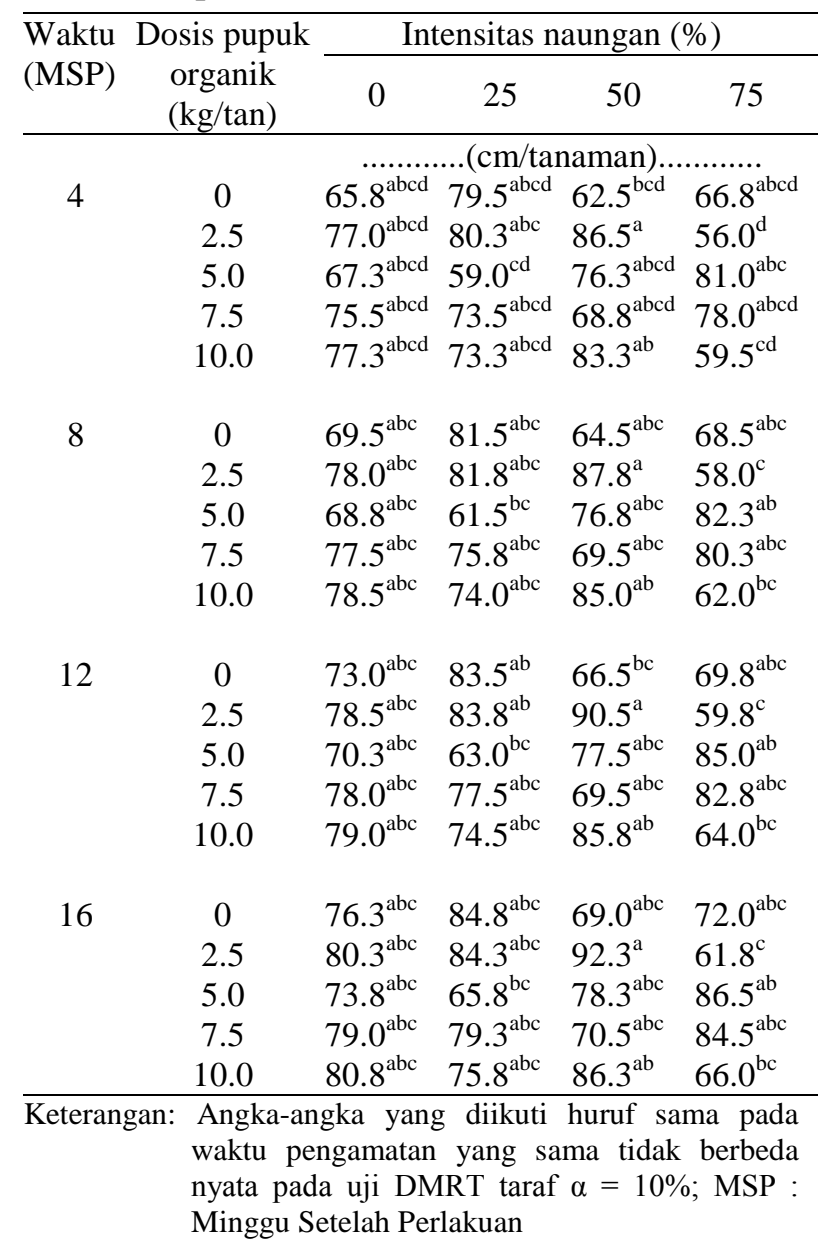

Dosis pupuk organic dan intensitas naungan optimum untuk pertumbuhan tinggi tanaman belum diperoleh hingga 16 MSP karena terlihat pada Gambar 1 hubungan antar dosis pupuk organik dengan intensitas naungan masih menunjukkan hubungan linear meskipun nilai Rnya tidak nyata. Hal ini menunjukkan bahwa ada kemungkinan waktu percobaan kurang lama sehingga akumulasi unsur hara yang diserap tanaman dari pupuk organik belum maksimal 
akibat dari sifat pelepasan unsur hara yang lambat (slow release). Selain itu juga disebabkan oleh naungan yang dipasang terlalu tinggi dan kurang lebar, sehingga mengakibatkan pengaruh naungan masih belum optimal terhadap tanaman cengkih belum menghasilkan.

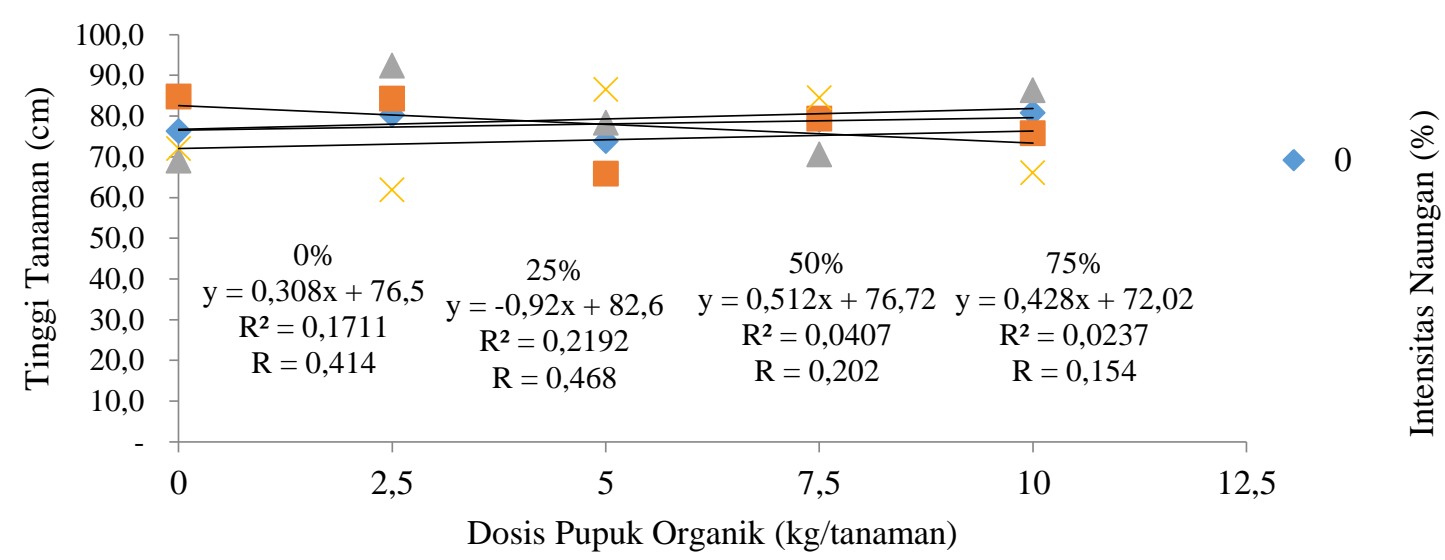

Gambar 1. Hubungan antara dosis pupuk organik dengan intensitas naungan terhadap tinggi tanaman cengkih belum menghasilkan pada 16 MSP

Pengaruh interaksi antara dosis pupuk organik dengan intensitas naungan terhadap diameter batang terjadi di awal masa pindah tanam yaitu umur 4,8 dan 12 MSP. Tanaman yang diberi pupuk organik $5 \mathrm{~kg}$ dengan intensitas naungan $75 \%$ nyata memiliki diameter batang yang lebih besar dibandingkan dengan perlakuan lainnya (Tabel 5).

Interaksi antara dosis pupuk organik dengan intensitas naungan pada umur-umur awal terjadi karena selama fase pertumbuhan vegetatif cadangan karbohidrat biasanya disimpan di bagian batang atau cabang, daun dan akar. Pada akhir percobaan tidak terdapat perbedaan antar perlakuan karena pada dasarnya unsur hara tersedia dalam tanah dimanfaatkan oleh tanaman sesuai dengan kebutuhan untuk pertumbuhan (Wachjar et al., 2002).

Sama halnya pada tinggi tanaman cengkih, pengaruh interaksi antara pupuk organik dengan intensitas naungan terhadap diameter batang menunjukkan hubungan linear meskipun nilai Rnya tidak signifikan (Gambar 2).
Tabel 5. Pengaruh dosis pupuk organik dengan intensitas naungan terhadap diameter batang tanaman cengkih belum menghasilkan pada umur 4,8 dan 12 MSP

\begin{tabular}{|c|c|c|c|c|c|}
\hline \multirow{2}{*}{$\begin{array}{l}\text { Waktu } \\
\text { (MSP) }\end{array}$} & \multirow{2}{*}{$\begin{array}{c}\text { Dosis pupuk } \\
\text { organik } \\
(\mathrm{kg} / \mathrm{tan})\end{array}$} & \multicolumn{4}{|c|}{ Intensitas naungan $(\%)$} \\
\hline & & 0 & 25 & 50 & 75 \\
\hline \multirow{6}{*}{4} & & & $\ldots(\mathrm{cm} / \mathrm{ta}$ & naman).. & \\
\hline & 0 & $0.6^{\text {cde }}$ & $0.6^{\text {cde }}$ & $0.6^{\text {cde }}$ & $0.6^{\text {cde }}$ \\
\hline & 2.5 & $0.6^{\text {abcde }}$ & $0.6^{\text {abcde }}$ & $0.6^{\text {abcde }}$ & $0.6^{\mathrm{abcde}}$ \\
\hline & 5.0 & $0.6^{\mathrm{abcd}}$ & $0.6^{\mathrm{abcd}}$ & $0.6^{\mathrm{abcd}}$ & $0.6^{\mathrm{abcd}}$ \\
\hline & 7.5 & $0.5^{\mathrm{de}}$ & $0.5^{\mathrm{de}}$ & $0.5^{\mathrm{de}}$ & $0.5^{\mathrm{de}}$ \\
\hline & 10.0 & $0.6^{\text {abcde }}$ & $0.6^{\text {abcde }}$ & $0.6^{\text {abcde }}$ & $0.6^{\text {abcde }}$ \\
\hline \multirow[t]{5}{*}{8} & 0 & $0.6^{\mathrm{bc}}$ & $0.6^{\mathrm{bc}}$ & $0.6^{\mathrm{bc}}$ & $0.6^{\mathrm{bc}}$ \\
\hline & 2.5 & $0.6^{\mathrm{bc}}$ & $0.6^{\mathrm{bc}}$ & $0.6^{\mathrm{bc}}$ & $0.6^{\mathrm{bc}}$ \\
\hline & 5.0 & $0.7^{\mathrm{abc}}$ & $0.7^{\mathrm{abc}}$ & $0.7^{\mathrm{abc}}$ & $0.7^{\mathrm{abc}}$ \\
\hline & 7.5 & $0.6^{\mathrm{bc}}$ & $0.6^{\mathrm{bc}}$ & $0.6^{\mathrm{bc}}$ & $0.6^{\mathrm{bc}}$ \\
\hline & 10.0 & $0.7^{\mathrm{abc}}$ & $0.7^{\mathrm{abc}}$ & $0.7^{\mathrm{abc}}$ & $0.7^{\mathrm{abc}}$ \\
\hline \multirow[t]{5}{*}{12} & 0 & $0.7^{\mathrm{b}}$ & $0.7^{\mathrm{b}}$ & $0.7^{\mathrm{b}}$ & $0.7^{\mathrm{b}}$ \\
\hline & 2.5 & $0.6^{\mathrm{b}}$ & $0.6^{\mathrm{b}}$ & $0.6^{\mathrm{b}}$ & $0.6^{\mathrm{b}}$ \\
\hline & 5.0 & $0.7^{\mathrm{ab}}$ & $0.7^{\mathrm{ab}}$ & $0.7^{\mathrm{ab}}$ & $0.7^{\mathrm{ab}}$ \\
\hline & 7.5 & $0.7^{\mathrm{b}}$ & $0.7^{\mathrm{b}}$ & $0.7^{\mathrm{b}}$ & $0.7^{\mathrm{b}}$ \\
\hline & 10.0 & $0.7^{\mathrm{ab}}$ & $0.7^{\mathrm{ab}}$ & $0.7^{\mathrm{ab}}$ & $0.7^{\mathrm{ab}}$ \\
\hline & $\begin{array}{l}\text { Angka-c } \\
\text { waktu } \\
\text { nyata p } \\
\text { Minggu }\end{array}$ & $\mathrm{ka}$ yang & diikuti & uruf san & $\begin{array}{l}\text { a pada } \\
\text { berbeda } \\
\text { MSP : }\end{array}$ \\
\hline
\end{tabular}




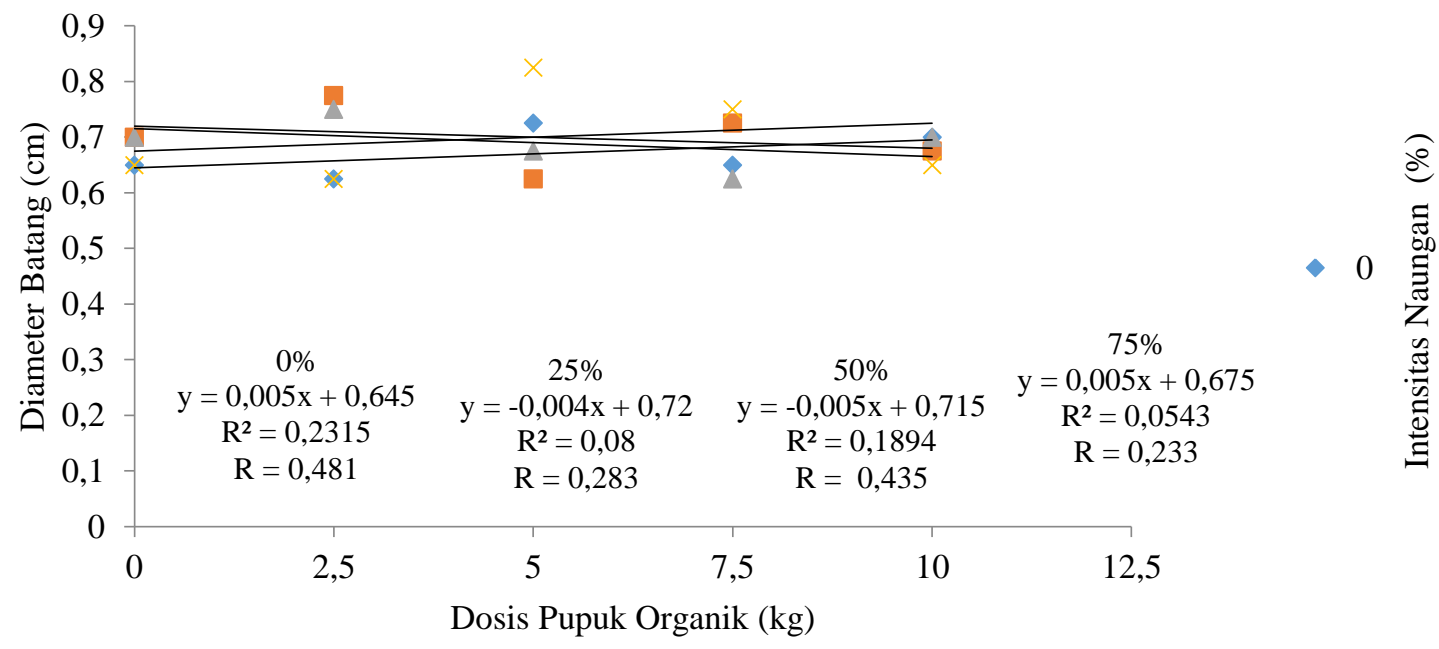

Gambar 2. Hubungan antara dosis pupuk organik dengan intensitas naungan terhadap diameter batang tanaman cengkih belum menghasilkan pada $12 \mathrm{MSP}$

\section{KESIMPULAN}

Hasil penelitian menunjukkan, bahwa dosis pupuk organik secara tunggal hanya cenderung berpengaruh nyata (uji $\mathrm{F}$ pada taraf $\alpha$ $10 \%)$ terhadap diameter tajuk tanaman cengkih pada umur 4 MSP. Dosis pupuk organik $10 \mathrm{~kg}$ per tanaman dapat meningkatkan diameter tajuk tanaman cengkih $30.0 \%$ dibandingkan dengan kontrol. Intensitas naungan secara tunggal tidak berpengaruh nyata terhadap pertumbuhan tanaman cengkih. Interaksi antara dosis pupuk organik dengan intensitas naungan hanya berpengaruh nyata terhadap diameter batang tanaman cengkih dan cenderung berpengaruh nyata (uji F pada taraf a 10\%) terhadap tinggi tanaman cengkih. Pemberian pupuk organik $2.5 \mathrm{~kg}$ per tanaman dengan intensitas naungan $50 \%$ cenderung meningkatkan tinggi tanaman cengkih sebanyak $20.9 \%$ dibandingkan kontrol pada 16 MSP, dan pemberian pupuk organik $5 \mathrm{~kg}$ per tanaman dengan intensitas naungan $75 \%$ dapat meningkatkan diameter batang tanaman cengkih sebesar 26.9\% dibandingkan dengan kontrol pada 12 MSP. Hasil penelitian belum menemukan taraf yang optimum baik untuk dosis pupuk organik maupun intensitas naungan. Hubungan antara dosis pupuk organik dan intensitas naungan menunjukkan hubungan linier meskipun nilai $\mathrm{R}$ nya tidak nyata.

\section{DAFTAR PUSTAKA}

[Balitan] Badan Penelitian dan Pengembangan Pertanian. 1979. Potensi Pengembangan Cengkih di Pulau Sumatera. Jakarta (ID): Kementerian Pertanian Republik Indonesia.
[Balitan] Badan Penelitian dan Pengembangan Pertanian. 2012. Peningkatan Produksi, Produktivitas dan Mutu Tanaman Rempah dan Penyegar: Cengkih. Jakarta (ID): Kementerian Pertanian Republik Indonesia.

[BMKG] Badan Meteorologi Klimatologi dan Geofisika. 2014. Data Curah Hujan Bulan September 2013 - Maret 2014. Bogor (ID): Stasiun Klimatologi Dramaga.

Bermawie, N. 1992. Cengkih. Buletin Penelitian Tanaman Rempah dan Obat 7(2):1-15.

Hadiwijaya, T. 1983. Cengkih, Data dan Petunjuk ke Arah Swasembada. Jakarta (ID): PT Gunung Agung.

Herman, Goenadi. 1999. Manfaat dan prospek pengembangan industri pupuk hayati di Indonesia. J. Penelitian dan Pengembangan Pertanian 18(3): 91-97.

Maryani, A, T., Gusmawartati. 2011. Pengaruh naungan dan pemberian kieserit terhadap pertumbuhan dan produksi tanaman nilam (Pogostemon cablin Benth.) pada medium gambut. J.I Agroteknologi 2(1):7-16.

Pangaribuan, D, H., Yasir, M., Novisha, K, U. 2012. Dampak bokashi kotoran ternak dalam pengurangan pemakaian pupuk anorganik pada budidaya tanaman tomat. J. Agronomi Indonesia 40(3):204-210. 
Santosa, E. 2003. Pengaruh jenis pupuk organik dan mulsa terhadap pertumbuhan tanaman lidah buaya (Aloe vera Mill.). Bul. Agron. 31(2):120-125.

Suarsana, M. 1986. Pemberian zat pengatur tumbuh mixtalol dan naungan dalam rangka rehabilitasi bibit cengkih (Eugenia caryophyllus Spreng.) [skripsi]. Bogor (ID): Institut Pertanian Bogor.
Wachjar, A., Setiadi, Y., Mardhikanto, L, W. 2002. Pengaruh pupuk organik dan intensitas naungan terhadap pertumbuhan bibit kopi robusta (Coffee cnephora Pierre ex Froehner). Bul. Agron. 30(1):6-11.

Wachjar, A., Kadarisman, L. 2007. Pengaruh kombinasi pupuk organik cair dan pupuk anorganik serta frekuensi aplikasinya terhadap pertumbuhan tanaman kakao (Theobroma cacao L.) belum menghasilkan. Bul. Agron. 35(3):212-216. 